\title{
Concept of Spirituality on Designing Fashion Products in Bali
}

\author{
Arini Arumsari \\ Doctoral Study of Visual Art and \\ Design Program \\ Institut Teknologi Bandung \\ Bandung, Indonesia \\ ariniarumsari@student.itb.ac.id
}

\author{
Agus Sachari \\ Faculty of Art and Design \\ Institut Teknologi Bandung \\ Bandung, Indonesia asachari@yahoo.com
}

\author{
Andryanto Rikrik Kusmara \\ Faculty of Art and Design \\ Institut Teknologi Bandung \\ Bandung, Indonesia \\ rikrik1212@yahoo.com
}

\begin{abstract}
In Balinese tradition, the process of designing fashion products that is a part of art and design domain, is an issue that cannot be separated from religion. Almost all sacred ceremonies require various rituals and offerings. Balinese Hindu community always delivers ritual and spiritual ceremonies passionately in order to give offerings to dewata (gods) in the forms of beautiful offerings, complex decorative ornaments, varied music, dances, theater, and so on. It shows that art is a very essential media for Balinese to preserve spiritual bond with niskala (the unseen). Balinese consider it is something extraordinary for its association of human creation and gods' gifts. Hence, many Balinese artists believe that it is a part of ritual or yadnya. In a previous research carried out by Tjokorda Istri Ratna Cora, the research output is the process of designing fashion products named "FRANGIPANI" method. The method reveals a very authentic typical phase of Bali, a phase of giving taksu. Furthermore, based on this research findings, a correlation between Design Ethic Concept conducted by Victor Papanek with the concept of Bayu-Sabda-Idep by I Wayan Dibia is found. It becomes a foundation in implementing Ethical Fashion practices applied by fashion brands belong to fashion designers or fashion brand owners from Bali. Thus, this qualitative research with social- cultural approach will expose about how the spiritual values inspire and be implemented on developing products and fashion brands owned by the present Balinese people, in the battle of hegemony with designers and entrepreneurs from outside Bali, not to mention the foreigners who own fashion brands in Bali.
\end{abstract}

Keywords : Fashion brands, spirituality values, taksu, Bali

\section{INTRODUCTION}

As an archipelago consisting of 34 provinces, Indonesia has different traditional cultures. However, one of the cultures which is still authentic and of which the traditional values are well maintained is that of Bali. In this study, the authentic traditional cultures of Indonesia to be discussed as the main topic are non-material cultural values (intangible heritage) including philosophical and spiritual values as well as their implementation on material cultural evidences (tangible heritage) as in the development of textile material and textile processing technique. Besides, they may also involve the development of the textile design process until it turns into clothes and is used for different purposes.

\section{LITERATURE REVIEW}

The followings will include some explanation on the background of the Balinese culture and belief, i.e. Hindu Dharma which underlies different values including the spiritual values of Balinese. In their daily lives, Balinese takes Hindu values and Tri Hita Karana philosophy as their reference to behave. The growth and development of Hindu (Hindu Dharma) in Bali mainly relates to the spread of Hindu (India) in Nusantara (the Indonesian archipelago) which is estimated to enter in the early of B.C. (Soekmono, 1991:7; Sumadio: 5-7)

Referring to the written evidence from the Ancient Bali era (the $8^{\text {th }}$ to the $14^{\text {th }}$ century) even from that of the early of the $15^{\text {th }}$ century, it can be seen that the theological conception deeply rooted in Hindu Dharma shows that the worship is aimed to the gods explained either in Indian patheon as cited in Veda and Purana books, which are the holy books of Hindu Dharma, or in the local belief which have been known since the prehistoric era. The religious understanding and internalization develop into different religious sects. However, the worship towards ancestral spirits rooted since the prehistoric era still becomes an integral part of their theological conception and religious value system of the people. (The History of Indonesian Culture: Religion and Philosophy (Sejarah Kebudayaan Indonesia: Religi dan Falsafah): 2009)

Balinese life philosophy is Tri Hita Karana, which emphasizes the harmony and balance of life among humans, between humans and the Creator, and humans and their environment. These principles are internalized and institutionalized in Balinese social structure and their way of life, in the development either of the knowledge system, behavioral patterns, attitude, values, tradition, art, or other issues.

Finally, the philosophy becomes an ideology and the core values of Balinese life and culture. It is this ideology which then becomes the basis for the basic rules used in the main institutions as kuren and dadia, sekaa (traditional organization) subak (water management system) and Pakraman Village in Bali, in evaluating the behaviour of the members.

Based on the cosmology of Balinese Hindu, Balinese see the world as a vertical entity consisting of three parts (loka). The highest part is swah loka, i.e. the place for Gods. The central part is bwah loka, which refers to the world where humans and other creatures live. However, the lowest part is bhur loka, i.e. the place for spirits and other lower power which are collectively called as bhuta kala (Dibia 2012: 8)

Humans living in the central world are always influenced by the higher and lower worlds so that they should always keep the harmony of all elements that may not only influence the central world or bwah loka which is the living place for humans - animals - and plants, but should also maintain the elements of life found in swah loka and bhur loka. Swah loka and bhur loka, which refer to nonphysical world, belong to niskala. However, bwah loka or the central world, the place where humans live, is 
the real world or sekala. In different world level, the ceremony held is also different, in line with the aims of the ceremony. Dewa Yadnya is a ceremony held for gods. Resi Yadnya, Pitra Yadnya and Manusa Yadnya are the ceremonies held for humans, animals, and plants in the real world. Furthermore, Bhuta Yadnya is the ceremony held for the spirits living in the other world.

Table 1. Panca Yadnya Ceremony in Sekala-Niskala and Triloka

\begin{tabular}{|c|c|c|}
\hline $\begin{array}{c}\text { Sekala Niskala } \\
\text { Principles }\end{array}$ & $\begin{array}{c}\text { Triloka } \\
\text { Principles }\end{array}$ & $\begin{array}{c}\text { Balinese Hindu } \\
\text { Panca Yadnya } \\
\text { Ceremony }\end{array}$ \\
\hline $\begin{array}{c}\text { Niskala } \\
\text { (Unreal / } \\
\text { nonphysical world) }\end{array}$ & $\begin{array}{c}\text { Shwah Loka } \\
\text { (God, gods and } \\
\text { other holy spirit) }\end{array}$ & Dewa Yadnya \\
\hline $\begin{array}{c}\text { Sekala (Real } \\
\text { world) }\end{array}$ & $\begin{array}{c}\text { Bwah Loka } \\
\text { (Humans, } \\
\text { animals, plants } \\
\text { and the others) }\end{array}$ & $\begin{array}{c}\text { Resi Yadnya } \\
\text { Pitra Yadnya }\end{array}$ \\
\hline $\begin{array}{c}\text { Niskala } \text { Yadnya } \\
\text { (Unreal / } \\
\text { nonphysical world) }\end{array}$ & $\begin{array}{c}\text { Bhuta Kala and } \\
\text { other evil spirits) }\end{array}$ & Bhuta Yadnya \\
\hline
\end{tabular}

Besides the spirituality values above, among the Balinese, there are also some unique social values which are different from other places in Indonesia. I Gusti Ngurah Bagus conveys that the kasta (caste) system is indeed found in Bali. Though it is different in terms of structure and function, there are some similarities to that of India, which is also based on Hindu. The caste in Bali is divided into four (caturwarna) including Brahmana, Ksatrya, Waisya and Sudra. The explanation on this is found in the Bila II bronze inscription dated in 995 Saka (1073 B.C.) from the era of Raja Anak Wungsu (Atmojo, 1991:60)

Later, there are also some experts in Bali introducing the terms of warna and wangsa for the caste system. Between the two terms, the term of wangsa is more common (Bagus, 1979).

The characteristics or identity of wangsa is depicted in the clan system, including the naming system. However, each wangsa has different traditions as representated in their wedding tradition. Wedding to a certain extent is tried to happen in the same wangsa. Mixed wedding, particularly the wedding between a woman from a higher wangsa to a man from a lower wangsa, is forbidden. In the era of Ancient Bali Kingdom, the violation towards the rule may lead to the death penalty. However, since the Dutch era, the death penalty was changed into a 10 year exile to an area outside Bali; the period of the punishment was then reduced into three years in 1937 and finally into a year (Bagus, 1979:110)

Each wangsa has its own dharma. However, as can be seen from Balinese, most of people do not perform the dharma in accordance with their wangsa anymore, except for the obligation of the Brahmana to be a monk or pedanda. Therefore, it can be clearly seen that the wangsa system has been gradually changed as the result of the influence of modern culture through different channels, as can be seen from Balinese recently. (The Book of Indonesian Culture: Social System (Buku Sejarah Kebudayaan Indonesia:

\section{Sistem Sosial))}

Pertaining to wangsa, in other literature, i.e. the book of Bali Art Ritual Performance, it is said that recently there is a tendency that democratization for the last hundred years has altered Balinese in different things. However, the hierarchy tendency is still strong. Traditional Balinese is highly hierarchical since it is built on the wangsa or kasta system. Three highest kasta known as triwangsa, namely Brahmana, Ksatria and Waisya, basically play a role as the ruler. However, the rest kasta, Jaba or Sudra coming from the outside of Puri wall, consists of the rest of population which is about 90 percent of the Balinese (Brinkgreve, 2010: 47)

Besides the social system of wangsa or kasta, Balinese also have a social system of village classification including Administrative Village and Pakraman or Indigenous Village. I Dewa Made Suartha says that Pakraman Village refers to a village for people to conduct the culture and religion in their social life.

The term of Pakraman Village is formally used in the Regional Regulation of the Province of Bali No. 3 Year 2001 on Pakraman village which is dated on March 21, 2001. In the Article 1 point 4 of the regulation it is said that:

Pakraman village is a costumary law community unit in the Province of Bali that has tradition and local custom of Hindu-based religion as hereditary on the bond of Kahyangan Tiga or Kahyangan Desa and has its own territory and wealth with the rights to manage for its home affair.

Kahyangan tiga is the implementation of Tri Murti, i.e. the worship towards the three main gods that control the human's life cycle including the birth, life, and death where everyone will pass the phase. The three main gods are:

a. Lord Brahma, the manifestation of the Almighty God or Ida Sang Hyang Widhi Wasa whose duty is as the creator which is placed at Pura Desa or Bale Agung (Village Temple).

b. Lord Wisnu (Vishnu), the manifestation of the Almighty God who has the duty of maintenance that is placed at Pura Puseh or Segara (Puseh Temple).

c. Lord Siwa (Shiva), the manifestation of God the Almighty whose duty is as pemralina or the healer which is placed at Pura Dalem (Dalem Temple).

Therefore, the home affair as well as different activities carried out by the village as managed under the Pakraman Village system refers to all related to ceremonies as well as other activities aimed at worshipping gods along with the implementation.

In Balinese social system, if it is found that if one has comitted some violations, there will consequently be some sanction or punishment as referred to the adat law (indigenous people's legal system). I Made Swastawa Dhamayuda says that the Balinese adat laws derived from Hindu always tries to create the balance condition among God, humans, and nature constructed in Tri Hita Karma lessons. Therefore, the violation towards the law causes some disturbance towards the cosmic balance patterned in sekala (real world) and miskala (unreal world) disharmony. The actions taken by the law officer/the Customary Chief/Bendesa Adat/Prajuru Adat are performed to restore the legal consideration, which is called by Teer Haar as Reactie tradition where it is later called by the people as customary sanction. Because the 
restoration towards harmony covers the real and unreal worlds, the sanction also refers to the real and unreal healing actions. It is later formulazied into pamidanda (punishment) in the form of sangaskara danda (punishment to hold a religious ceremony), artha danda (punishment to do some payment either that of money or of wealth), and jiwa danda (physical of psychological punishment).

However, I Made Windyana suggests that customary sanction is one of the customary reactions towards the violation of the customary regulations. The sanction is aimed at restoring the balance which has been disturbed as the result of the violation. It always comes after an incident or an action that should be called to account by the either the violator or the family. It is common that the action or the incident coming after the sanction comes with a ceremony which is in Bali known as pemarisuddhan, that refers to the ceremony to clean the (customary) village, i.e. from the dirty power of the other world. It is not aimed as a punishment or torture, yet it is aimed at healing the cosmic balance.

\section{PROBLEM STATEMENTS}

Based on the explanation obtained from the literature study above, it can be seen that Hindu Dharma lessons as well as their different implementations are taken as the basic of life for Balinese. They are also taken as the guidance for Balinese in making some works in different fields including in fashion. Fashion in Bali to be discussed in this study cannot be separated from its origin, i.e. Balinese traditional fabric and traditional clothes. In this study, there will also be some explanation on how the spirituality values of Hindu Dharma in Balinese may influence the material process as well as the technique used in the making of traditional fabric and traditional clothes which finally develops into fashion product in Bali recently.

\section{METHODOLOGY}

The methodology used in this study is qualitative method with sociology approach. Sachari (2002: 8) says that sociology method is comprised by two big groups of pure and applied sociological methods. Applied sociological method is aimed at planning a strategy to solve a certain social problems or to plan some social policies related to the development to carry out. Specifically, sociological approach taken is design sociology.

Design sociology in specific, however, is the field of knowledge focusing on individual, a group or a society behavior influed by a certain design works. The development of design sociology is encouraged by the complex condition of designs related to the human life (Sachari, 2002: 10). In this study, the design work refers to the fashion products growing in Bali recently, which are derived from the development of Balinese traditional fabric and clothes. The approach is used either to explain the social field and social analysis or to give some reference for the players in fashion industry in Bali, i.e. through a new social policy as well as some fresh design approaches innovatively marking that the underlying spirituality and philosophical values have been left.

\section{RESULT OF ANALYSIS}

Pertaining to the unique of the work method, particularly in Balinese fashion, Tjokorda Istri Ratna Cora Sudharsana has also conducted a study in crafting, specifically, i.e. in fashion product design. There are ten steps of designing process recommended to do by the players in fashion industry in Bali. The ten steps are covered in a method called as "FRANGIPANI". The method is aimed at finding some solutions in facing cultural hegemony as well as foreign players in the fashion industry in Kuta. Specifically the 10 steps of the "FRANGIPANI" method are: (1) Finding some triggering ideas derived from the Balinese culture, (2) Doing some research to find some ideas for the fashion products to make, (3) Analyzing the aesthetic elements derived from Balinese culture, (4) Narrating ideas obtained through some sketch or even a two or three dimentional prototypes, (5) Giving some taksu to the product design, (6) Interpreting the unique of the fashion design to the real product, (7) Promoting the real fashion product, (8) Doing some brand affirmation, (9) Leading the fashion production to a humanist capitalist system, (10) Introducing a unique fashion business method (Sudharsana: 2016)

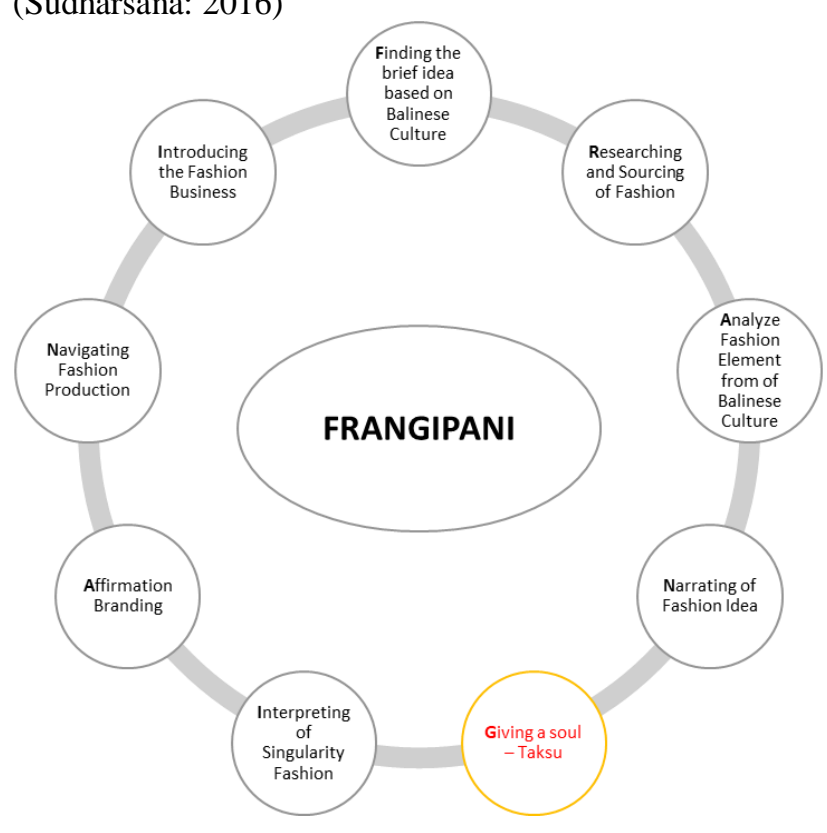

Figure 1. Frangipani

Concept, The Secret Step for Art Fashion (Sudharsana: 2016)

The unique of "FRANGIPANI" method is that among the ten steps, there is an acculturation between the fashion product design theories in general and the one specific to Bali that turns out to be the identity of the players in fashion industry from Bali. The step here refers to the steps in giving taksu.

In Balinese tradition, the fashion product design, which is also a part of art and design, cannot be separated from religion. Most of religious ceremonies require art presentation and each of art presentation at all time involves different rituals and performances. Balinese always do rituals and hold religious ceremonies wholeheartedly in order to give some performances to their gods, i.e. by having some lovely performances, intricate decorative crafts, different music, dances, theaters, etc. It shows that art is an important medium for Balinese in maintaining their spiritual relation with 
niskala world. Balinese consider something to be special as it is a combination of human creation and the gift from God. Therefore, a number of Balinese artists consider doing some art performances as a part of ritual or yadnya.

Furthermore, taksu referred in FRANGIPANI concept above as found in the belief of Balinese are as follow:

\section{Taksu Bekel}

Taksu Bekel, the seed of taksu possessed since the birth which can be developed in a certain efforts either physically, mentally or spiritually.

\section{Taksu Paica}

Taksu Paica, taksu derived from a holy spirit of Hyang Kuasa given to humans. The energy is developed into different ritual or religious ceremonies.

\section{Taksu Gegaen}

Taksu Gegaen, taksu derived from talisman from monks or sometimes called as shaman.

Based on the belief above, taksu may refer to the spirit derived from Hyang Kuasa. Therefore, the artists believing and needing for the presence of taksu in their art works believe that there are some places they can visit to beg for taksu.

Taksu is not automatically passed from one generation to another. There are also some parties who may be able to have taksu in their works while there are also the vice versa. Therefore, taksu can be possessed by anyone who does some hard work. When someone has taksu in his works, it is when he is in his real consciousness. Though it is full of spiritual and mystical values, taksu is different from trans where the artists are inconscious.

Based on the reference, taksu does not always connect to someone. For example, taksu does not always come to one's works. Even, for instance, among some art work collections there is one of the works having no taksu.

Based on the explanation above, it can be inferred that taksu is related to one's works. It is not related to the artist or the person who makes the art works. Therefore, the characteristics of taksu in an art work are:

\section{Idup}

Idup is being alive or having a soul. It can also be said that the work has the light of life.

\section{Lengut 3. Jaen}

Lengut is good, proper, fit in, appropriate or mature.

Jaen is derived from the term of tasting sense referring to delicious. It can also be defined as something that can be used to meet his intention, make someone full, or has a high taste.

In order to gain taksu in the process of creating artwork, Ida Pedanda Singarsa proposes that an artist or other experts should always unite his thought, word or speech, and actions in line with the Tri Kaya Parisudha principles. The principles include Bayu-Sabda-Hidep aspects. The position and interrelation of the three aspects covered in the three pillars of taksu is illustrated in the following scheme.

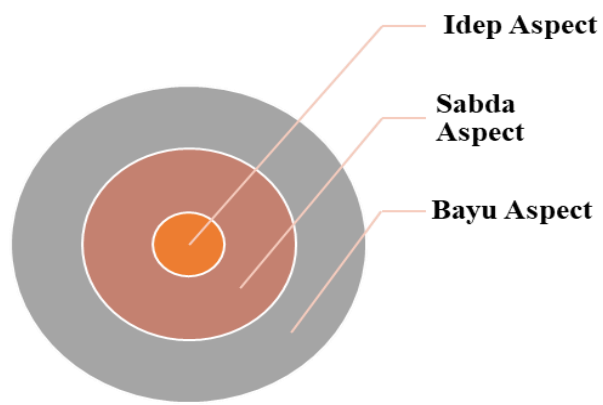

Fig 2. Position and the interrelation of the Bayu-Sabda-Idep principle Dibia, 2012

The biggest circle in Вауи aspect relates to the technique skill and material mastery required by the art works. The mastery towards all which can be found in this aspect is the basic and the first thing that should be mastered by the artist in making some art works. The central circle in Sabda aspect relates to the rules and requirements pertaining to the mental and moral aspects. An artist should understand these mental and moral aspects after mastering the elements in Bayu aspect. The inner circle, Idep, is all related to spiritual and magic values in an art work. The elements in Idep aspect can finally be mastered after the artist has mastered the other two aspects, i.e. Bayu and Sabda.

In the other implementation, the principles are also related to the Satyam-Shivam-Sundaram principles which refer to the elements that should be found in an excellent Balinese art work. In the following scheme, there is also a map on how the principlese can be carried out in the process in creating artwork carried out by a Balinese artist.

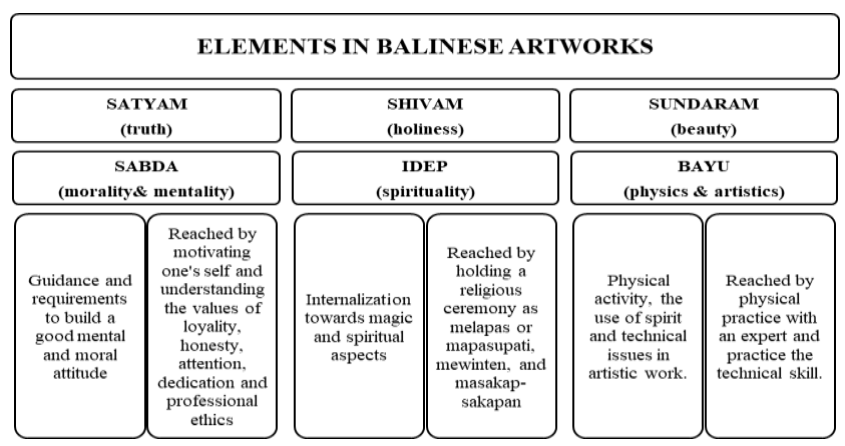

Fig 3. Chart of the Elements on an Excellent Balinese Art Work Dibia, 2012

Based on the findings above there is some correlation between Bayu-Sabda-Idep concepts of I Wayan Dibia and the Design Ethnic concept of Victor Papanek, which become the basis in the development of design product including the go green fashion product. The concept in the design and fashion is covered in eco design, green design, sustainable design, and ethical design concepts. 
Table 2. The Correlation between Bayu-Sabda-Idep and Design Ethic Concepts

\begin{tabular}{|c|l|c|}
\hline $\begin{array}{c}\text { BayuSabda- } \\
\text { Idep } \\
\text { Concept }\end{array}$ & \multicolumn{1}{|c|}{ Similarities } & $\begin{array}{c}\text { Design } \\
\text { Etchic } \\
\text { Concept }\end{array}$ \\
\hline Bayu & $\begin{array}{l}\text { Material mastery and skill } \\
\text { in making a product or } \\
\text { some work in realizing } \\
\text { aesthetic, artistic, and } \\
\text { creative values }\end{array}$ & $\begin{array}{c}\text { Beauty, art and } \\
\text { creativity values }\end{array}$ \\
\hline Sabda & $\begin{array}{l}\text { Guidance and requirement } \\
\text { in building a good mental } \\
\text { and moral attitude } \\
\text { through honesty, } \\
\text { attention, }\end{array}$ & $\begin{array}{c}\text { Ecological } \\
\text { Responsibility \& } \\
\text { Social Justice }\end{array}$ \\
\hline Idep & $\begin{array}{l}\text { Enrichment towards magic } \\
\text { and spiritual aspects }\end{array}$ & Spiritual Values \\
\hline
\end{tabular}

Based on the table above, the guidance in understanding the implementation of go green concept in fashion business in Bali will refer to Bayu-Sabda-Idep spirituality concept. Therefore, the checklist for the future observation will be derived from the points in the concept.

\section{DISCUSSION}

Based on the explanation above, the spirituality values taken as the basis for Balinese to make an art work including the one in fashion should be implemented in the elements that can be practiced in a direct artistic process. The following, for instance, tries to map of the realization on what have been done by some fashion business owners in Bali who process natural fabric and dye in their product development.

The business fashion here refers to: Surya Indigo, Tarum Bali, Bali Artha Nadi and Ikat Batik. The five fashion businesses are chosen based on some direct observation conducted in Bali aimed at investigating and describing fashion businesses practicing the go green technique and material development in their product designs. The following is a short profile of the fashion businesses:

Table 3. Profile of the fashion business in Bali

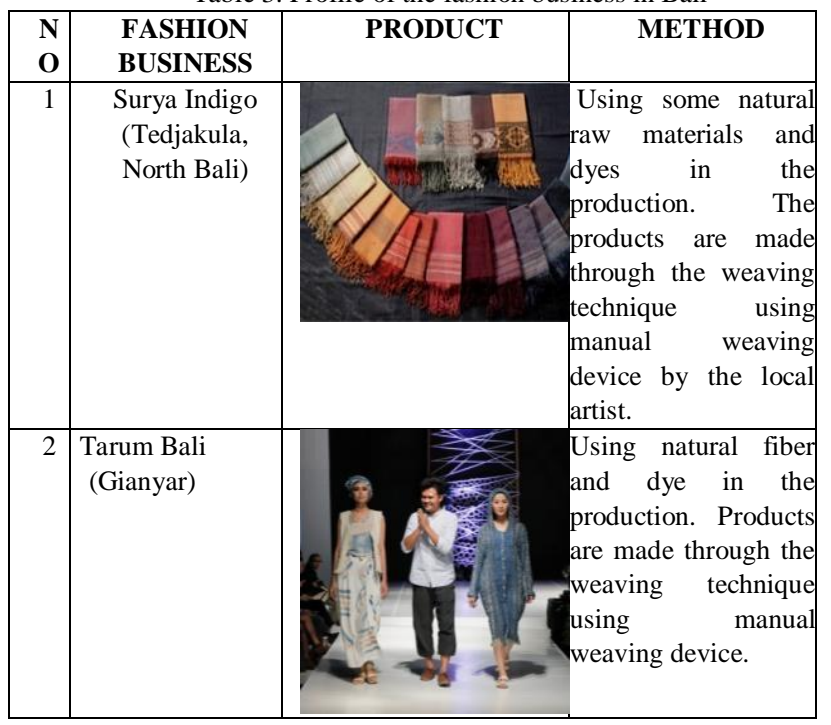

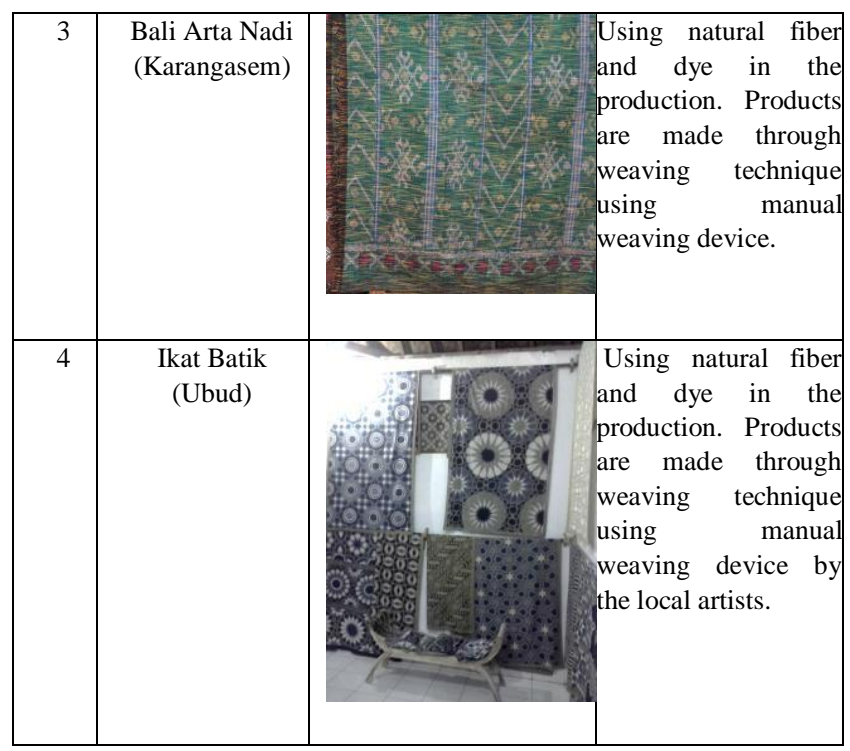

The following is an analysis on how fashion businesses above implement Bayu-Sabda-Idep concept in their fashion product development.

Table 4. Result of the Analysis towards the Implementation of BayuSabdaIdep on fashion business in Bali

\begin{tabular}{|c|c|c|c|c|}
\hline $\begin{array}{l}\mathbf{N} \\
\mathbf{O}\end{array}$ & $\begin{array}{l}\text { FASHION } \\
\text { BUSINESS }\end{array}$ & $\begin{array}{c}\text { BAYU } \\
\text { ASPECT } \\
\text { (Aesthetics) }\end{array}$ & $\begin{array}{c}\text { SABDA } \\
\text { ASPECT } \\
\text { (Ecologi \& } \\
\text { Social Justice) }\end{array}$ & $\begin{array}{c}\text { IDEP } \\
\text { ASPECT } \\
\text { (Spiritual } \\
\text { Value) }\end{array}$ \\
\hline 1 & Surya Indigo & $\begin{array}{ll}\text { - } \begin{array}{ll}\text { Exploration } \\
\text { natural dye }\end{array} \\
\\
\text { - Exploration } \\
\text { weaving } \\
\text { technique } \\
\text { particularly } \\
\text { gedhog, on } \\
\text { weaving device }\end{array}$ & $\begin{array}{l}\text { The use of natural fiber \& } \\
\text { dye as the raw materials } \\
\text { - Using gedhog weaving } \\
\text { device in the production of } \\
\text { fabrics. } \\
\text { Empowerin } \\
\text { g banjar local people }\end{array}$ & $\begin{array}{l}\text { Holding a } \\
\text { daily } \\
\text { religious } \\
\text { ceremony in } \\
\text { the } \\
\text { production } \\
\text { process } \\
\text { carried out } \\
\text { in a } \\
\text { workshop. }\end{array}$ \\
\hline 2 & $\begin{array}{c}\text { Tarum Bali } \\
\text { Sejahtera }\end{array}$ & $\begin{array}{l}\text { - Exploration on } \\
\text { natural dye since } \\
2001 \\
\text { - Exploration on } \\
\text { weaving } \\
\text { technique. } \\
\text { - Exploration on } \\
\text { recycle material / } \\
\text { technique. }\end{array}$ & $\begin{array}{l}\text { - The use of natural fiber \& } \\
\text { dye as the raw material. } \\
\text { - Using non machine } \\
\text { weaving } \\
\text { device or Alat } \\
\text { Tenun Bukan } \\
\text { Mesin } \\
\text { (ATBM) in the production } \\
\text { of fabrics. } \\
\text { Empowerin } \\
\mathrm{g} \text { local banjar people. } \\
\text { - There is a long break time } \\
\text { on weekday time } \\
\text { There is a pool to manage } \\
\text { the waste of the production } \\
\text { in the workshop }\end{array}$ & $\begin{array}{l}\text { Holding a } \\
\text { daily } \\
\text { religious } \\
\text { ceremony in } \\
\text { the } \\
\text { production } \\
\text { process } \\
\text { carried out } \\
\text { in a } \\
\text { workshop } \\
\text { The layout } \\
\text { of the } \\
\text { workshop } \\
\text { building is } \\
\text { in } \\
\text { accordance } \\
\text { with the } \\
\text { Balinese } \\
\text { cultural } \\
\text { rules. }\end{array}$ \\
\hline 3 & $\begin{array}{c}\text { Bali Arta } \\
\text { Nadi }\end{array}$ & $\begin{array}{l}\text { The unique of } \\
\text { double ikat } \\
\text { weaving on the } \\
\text { fabric creates a } \\
\text { special motif. }\end{array}$ & $\begin{array}{l}\text { The use of natural fiber } \\
\text { and dye as the raw } \\
\text { materials. } \\
\text { - Using non machine } \\
\text { weaving device and } \\
\text { gedhog in the production } \\
\text { of fabrics. } \\
\text { - Empowering local banjar } \\
\text { people. }\end{array}$ & $\begin{array}{l}\text { Holding a } \\
\text { daily } \\
\text { religious } \\
\text { ceremony in } \\
\text { the } \\
\text { production } \\
\text { process } \\
\text { carried out } \\
\text { in a } \\
\text { workshop. }\end{array}$ \\
\hline
\end{tabular}




\begin{tabular}{|c|c|c|c|c|}
\hline 4 & Ikat Batik & $\begin{array}{l}\text { A unique blue } \\
\text { produced from } \\
\text { indigo. } \\
\text { Exploration on the } \\
\text { motiffs derived } \\
\text { from different } \\
\text { cultures in the } \\
\text { world. }\end{array}$ & $\begin{array}{l}\text { The use of natural fiber \& } \\
\text { dye as the raw materials } \\
\text { Using non machine } \\
\text { weaving device and } \\
\text { gedhog in the production } \\
\text { of fabrics. } \\
\text { Empowering } \\
\text { ocal banjar people } \\
\text { A flexible and beneficial } \\
\text { working hours for the } \\
\text { workers. }\end{array}$ & $\begin{array}{l}\text { Holding a } \\
\text { daily } \\
\text { religious } \\
\text { ceremony in } \\
\text { the } \\
\text { production } \\
\text { process } \\
\text { carried out in } \\
\text { a workshop. }\end{array}$ \\
\hline
\end{tabular}

\section{CONCLUSION}

Based on the study it can be concluded that Balinese taking Hindu Dharma as the basis for their life using the aspects in Hindu Dharma lessons including spirituality aspect as the basis and guidance in their daily life. In terms of fashion which tightly relates to the art, the spirituality concept is specifically defined in Bayu-Sabda-Idep concept as explained in the analysis table above. The concept becomes the basis in making the art works produced have some taksu where the existence of taksu in an art work or a design is a sign that the goal has been realized, i.e. to make an excellent art work in accordance with Balinese belief. It is the belief that an art work is created in accordance with the Tri Hita Karana principle in Hindu Dharma lesson that humans should maintain the harmony and balance of life, among humans, humans and the Creator, as well as between human and the environment.

\section{ACKNOWLEDGMENT}

A sincere thank you to RISTEK-DIKTI for funding the research through the Doctoral Dissertation Research Scheme for the Budget Year of 2017/2018.

A sincere thank you as well as high appreciation to Dr. Tjokorda Istri Ratna Cora Sudharsana, a researcher from Insitut Seni Indonesia - Denpasar for abundant thought given through her previous research.

\section{REFERENCES}

[1] Dibia, I Wayan. (2012): Taksu Dalam Seni dan Kehidupan Bali. Denpasar - Indonesia: Bali Mangsi

[2] Nilotama, Sangayu Ketut Laksemi. (2009): Makna Simbol Gelar Raja Dalam Masyarakat Adat Bali. Indonesia: Jurnal Visual Art \& Desain ITB Vol. 3, No. 1, 2009, 43-56

[3] Paeni, Mukhlis. (2009): Sejarah Kebudayaan Indonesia: Seni Rupa dan Desain. Jakarta - Indonesia: Rajawali Pers

[4] Paeni, Mukhlis. (2009): Sejarah Kebudayaan Indonesia: Religi dan Falsafah. Jakarta - Indonesia: Rajawali Pers

[5] Paeni, Mukhlis. (2009): Sejarah Kebudayaan Indonesia: Sistem Sosial. Jakarta - Indonesia: Rajawali Pers

[6] Papanek, Victor. (1995): The Green Imperative: Ecology and Ethics in Design and Architecture. London: Thames and Hudson

[7] Suartha, I Dewa Made. (2015): Hukum dan Sanksi Adat, Perspektif Pembaharuan Hukum Pidana. Indonesia: Setara Press

[8] Sudharsana, Tjok Istri Ratna Cora. (2016): Global Fashion Discourse In Cosmopolitan Kuta. International Journal of Multidisciplinary Educational Research Vol 5, Issue 8 (1), August 2016

[9] Tim Kementrian Kebudayaan dan Pariwisata Republik Indonesia. (2010): Tenun Ikat, Indonesia's Ikat Weaving Traditions.Indonesia 